\title{
GEOCHEMICAL FINGERPRINTS OF CLIMATIC OSCILLATIONS DURING THE LATE Holocene in Ria de Vigo (N SPAIN)
}

\section{MARIA VIRGÍNIA ALVES MARTINS ${ }^{1,2 *}$, JOÃO MANUEL ALVEIRINHO DIAS ${ }^{3}$, MIGUEL ÂNGELO MANE ${ }^{1}$ AND FERNANDO ROCHA ${ }^{2}$}

1 Universidade do Estado do Rio de Janeiro (UERJ), Faculdade de Geologia, Departamento de Estratigrafia e Paleontologia. Av. São Francisco Xavier, 524, sala 2020A, Maracanã, 20550-013, Rio de Janeiro, RJ, Brazil.virginia.martins@ua.pt

2 Geobiotec, Universidade de Aveiro, Departamento de Geociências, Campus de Santiago, 3810-193, Aveiro, Portugal. tavares.rocha@ua.pt

3 Centro de Investigação Marinha e Ambiental (CIMA), Universidade do Algarve, Campus de Gambelas, Faro, Portugal. jdias@ualg.pt

*Corresponding Author, virginia.martins@ua.pt

Received on 30 December 2015

Received in revised form on 21 January 2016

Accepted on 04 February 2016

Editor:

Maria Antonieta da Conceição Rodrigues, Universidade do Estado do Rio de Janeiro, Brazil

\begin{abstract}
This work studies mineralogical data from X-Ray Diffraction Techniques (XRD) and geochemical data analyzed by Inductively Coupled Plasma Mass Spectrometry (ICP-MS) of fine fraction from samples collected along the Ocean Margin Exchange Project (OMEX) core KSGX 24. This core was recovered in the external sector of Ria de Vigo, N Spain. Radiocarbon ages allowed the estimation of an age about $3 \mathrm{ka} \mathrm{cal} \mathrm{BP}$ for the core base. Core KSGX 24 is a muddy sedimentary sequence with two main sections where the sediments are finer: $\approx 134-90 \mathrm{~cm}$ and $\approx 26-0 \mathrm{~cm}$. These finer sections are characterized by a relatively low sedimentation rate, and by changes in the geochemical and mineralogical composition of the sediments and their magnetic susceptibility. Basically, they are relatively depleted in carbonates and $\mathrm{Ca}$ content, and relatively enriched in detrital minerals, namely phyllosilicates, and in $\mathrm{Al}$, Co and Sc. The slightly coarser grained intercalated sections are
\end{abstract}

\section{Introduction}

Since the 1960s the scientific community has making significant efforts to characterize and study the factors that conditioned sedimentation off the Iberian Margin, from the late Quaternary. The works of Duplaix et al. (1965), Monteiro and Moita (1971), Kudrass (1973, 1993), Siedler
Citation:

Martins, M.V.A., Dias, J.M.A., Mane, M.Â., Rocha, F., 2016. Geochemical fingerprints of climatic oscillations during the late Holocene in Ria de Vigo (N Spain). Journal of Sedimentary Environments, 1(1): 78-89.

marked by the increase of Ce, La and Th content. These results suggests that, despite the prevalence of a weak hydrodynamic regime in the study area during the last $3 \mathrm{ka}$, it has undergone some changes. The mineralogical and geochemical deviations may have been conditioned by several factors, such as: authigenetic and diagenetic reactions; anthropogenic activities in the nearby continental region; the natural tendency for sea level rise; changes in hydrodynamic conditions regulated by modifications in the pattern of prevailing winds; and alterations in the rainfall regime. The two last factors are related to climate oscillations and probably with the tendency of the North Atlantic Oscillation (NAO) to remain more positive or negative during longer periods in the past than at present.

Keywords: Sediment. Mineralogy. Geochemical fingerprint. Climatic oscillations. Coastal system.

and Seibold (1974), Thiede (1977), Monteiro et al. (1980), Gonthier et al. (1984), Fedo et al. (1996), Stow et al. (1986), Vanney and Mougenot (1990), Abrantes (1991), Lebreiro et al. (1996), Schönfeld (1996), Baas et al. (1997), Zahn et al. (1997), Martins et al. (2013a, 2015a and references herein) were contributions that sought to understand the processes that affected the recent evolution of the Iberian Margin. 
Compared with the last glacial period, the Holocene can be considered as quite a stable epoch. However this stability has been increasingly questioned (e.g. Meese et al., 1994; O'Brien et al., 1995; Bond et al., 1997; Bianchi and McCave, 1999; deMenocal et al., 2000; Mayewski et al., 2004). Studies performed in the Iberian Peninsula, based on paleoflood records, indicated several changes in the frequency and magnitude of river floods, and therefore, in precipitation related to climatic variability, during the late Holocene (Thorndycraft and Benito, 2006). Several other studies also indicated changes in the rainfall regime of the Iberian Peninsula during the late Holocene (e.g. Abrantes et al., 2005; Bartels-Jónsdóttir et al., 2006; Lebreiro et al., 2006; Gil et al., 2006). Bernárdez et al. (2008) related such changes to North Atlantic Oscillations (NAO).

The NAO describes the varying air-pressure gradient between the Azores High and the Iceland Low (e.g. Hurrell, 1995). The intensification of precipitation over the Iberian Peninsula is negatively correlated with the NAO index (Trigo et al., 2004; Vicente-Serrano and Heredia-Laclaustra, 2004), whereas the intensification of the northerly wind strength, which drives coastal upwelling along the Portuguese margin, shows a positive correlation with NAO (Oschlies, 2001). Today, the NAO varies on short timescales, however there is some evidences that the NAO may have shown, in the past, a tendency to exhibit positive or negative values over longer periods (e.g. Álvarez et al., 2005; Bartels-Jónsdóttir et al., 2006; Lebreiro et al., 2006).

Recent high-resolution studies based on Holocene records were performed in the NW Iberian Peninsula, seeking to characterize major climatic changes and their influence in the Iberian Margin and in the evolution of transitional settings (e.g. Martínez-Cortizas et al., 1999; Diz et al., 2002; Desprat et al., 2003; Abrantes et al., 2005; Álvarez et al., 2005; González-Álvarez et al., 2005; Martins et al., 2005, 2006a, 2006b, 2007, 2013b; Bartels-Jónsdóttir et al., 2006; Lebreiro et al., 2006; Bernárdez et al., 2008).

Currently, the main features of the shelf that define the transport and deposition of fine sediments in the NW Iberian Margin were explained by Dias et al. (2002a, b). The influence of these conditions in sediment mineralogical and geochemical composition was analyzed, for instance, by Araújo et al. (2002, 2007) and Oliveira et al. (2002). Recent sedimentation and sedimentary budgets on the NW Iberian shelf were studied by Jouanneau et al. (2002).

Sediment mineralogical and geochemical composition are controlled by several factors, including tectonic setting, source rock composition and weathering, erosion, transportation, sedimentation, and diagenetic processes (McLennan, 1989; McLennan et al., 1993; Underwood et al., 1993; Fedo et al., 1996; Astakhov et al., 1995; Crowley et al., 1998; Chen et al., 2011; Tao et al., 2013). Climate has a fundamental role in rock weathering, erosion, and transportation and sedimentation processes (Bischoff et al., 1997; Yuretich et al., 1999; Bischoff and Cummins, 2001; Thamban et al., 2002; Yuretich and Ervin, 2002; Jason et al., 2005; Diekmann et al., 2008).

Fragments of minerals eroded from source rocks and chemical elements are transferred into clastic sediments during rock weathering (McLennan and Taylor, 1991; Gu et al., 2002). Therefore, a variety of important proxies based on mineralogical and geochemical data have been applied to study clastic rock provenance and tectonic settings (Dickinson and Suczek, 1979; McLennan and Taylor, 1991; Schieber, 1992; Fedo et al., 1996; Tao et al., 2013). Among chemical elements, REE distribution patterns are useful indicators of geological processes and sediment provenance (Cullers et al., 1979, 1987, 1988; Taylor and McLennan, 1985; Bhatia and Crook, 1986; Cullers and Stone, 1991; McLennan et al., 1993; Cullers and Berendsen, 1998).

On the basis of grain size, magnetic susceptibly, mineralogical and geochemical data, this study seeks to identify and characterize changes in the sedimentary dynamics of a muddy area located in the external sector of Ria de Vigo, N Spain, during the late Holocene. This work also aims to relate these changes with possible conditioning factors.

\subsection{Study area}

The Ria de Vigo is situated in Galicia, NW Spain, and belongs to a vast complex of coastal embayments called Rias Baixas, located between the latitudes of $42^{\circ} \mathrm{N}$ and $43^{\circ} \mathrm{N}$. The Rias Baixas were formed due to reactivation of the Variscan tectonic fault that created sunken valleys, which were later invaded by the sea (Torre, 1958; Vidal Romani, 1984).

The lithology of the continental areas surrounding the Ria de Vigo contributes to the sediment composition of this system (e.g. Caetano et al., 2009) and influence the coastal sediments in the Galicia region (Prego et al., 2012). The lithology of the NW Iberian Peninsula, in northern Spain, namely the Galicia region, is composed of different continental geological complexes, such as: Ortegal-Ordes, Malpica-Tuy, Brangança and Morais ophiolitic units, the Galiñeiro orthognaissic Complex and the Ollo-de-Sapo Domain. The lithology and tectonic details of these 
continental formations have been studied by several authors (e.g. Ortega and Gil-Ibarguchi, 1990; Pin et al., 2002).

The Ria de Vigo, with an area of approximately $176 \mathrm{~km}^{2}$, has a tapered shape of NNE-SSE orientation, with a central axis $33 \mathrm{~km}$ long. The central channel major axis has a maximum depth of $45 \mathrm{~m}$ at the mouth (Álvarez et al., 2005). The mouth is partially limited by the Cies Islands, creating two relatively narrow aisles at the entrances of the northern and southern parts. These apertures allow the interconnection with the ocean, and result in relatively calm conditions in this ria (Vilas et al., 1995, Fig. 1).

Circulation inside the Ría de Vigo follows an estuarine pattern, with a deep current flow entering this system and a surface water flow exiting it (García-Gil et al., 1995). This general pattern changes seasonally due to the influence of the Azores High pressure center. During the summer, a northerly anticyclonic wind circulation, linked to the Azores High belt, reinforces the estuarine pattern (Álvarez-Salgado et al., 1993) and strengthens the upwelling (Fiuza et al., 1982; Blanton et al., 1987; Tenore et al., 1995; Figueiras et al., 2002). The strongest upwelling phases cause mixing in the Ria de Vigo water column (Álvarez et al., 2005).

During spring-summer, due to the action of northerly winds on surface waters, the current direction along the continental shelf is to the south (Peliz et al., 2002). On the other hand, during winter, the dominant southerly wind regime gives place to a rainy season and downwelling conditions, which generate a poleward flow along the continental shelf (Haynes and Barton, 1990).

The Ria de Vigo is a highly productive system, due to the runoff influence of several small rivers (the bigger ones are Vergudo and Oitaven), and to municipal discharge of effluents, which introduced anthropogenically-produced nutrients and high amounts of organic matter (Prego, 1993). The upwelling system, which result in lower surface water temperatures, also introduces high nutrient contents. The abundant availability of nutrients generates high primary production in this ria (Prego, 1993; García-Gil et al., 1995; Álvarez-Salgado et al., 1996; Figueiras et al., 2002).

\section{Material and methods}

This work reanalyzes some textural and mineralogical data obtained by Martins et al. (2013b), and new geochemical and magnetic susceptibility results in core KSGX $24(236 \mathrm{~cm}$ long). This core was collected in an oceanographic cruise conducted under the OMEX project (Ocean Margin Exchange Project), in the external sector of the Ria de Vigo, near the Cies Isles (at latitude $42^{\circ} 12^{\prime} 48^{\prime \prime} \mathrm{N}$, longitude $8^{\circ} 51^{\prime} 90^{\prime \prime} \mathrm{W}$ and $39 \mathrm{~m}$ water depth). The core was sampled every centimeter along its full length. Mineralogical and textural data were obtained every centimeter, and geochemical data was sampled every $2 \mathrm{~cm}$ along the core.

The texture of the sediment was determined with a micro laser granulometer (Malvern Master Size), after eliminating organic matter and carbonates. The magnetic susceptibility $(\chi)$ of the sediment was measured on dried bulk sediment samples (at every centimeter). Measurements were done with a portable KT-9 Digital Magnetic Susceptibility Meter, by taking 10 successive readings per sample and using the mean of obtained values.

The mineralogical analysis was carried out using $\mathrm{X}$-ray diffraction techniques in sedimentary fractions $<63 \mu \mathrm{m}$ (silt plus clay fractions), using Philips PW1130/90 and X'Pert PW3040/60 equipment, and $\mathrm{Cu} \mathrm{K} \alpha$ radiation. Scans were run between $2^{\circ}$ and $40^{\circ} 2 \theta$. Qualitative and semiquantitative mineralogical analyses followed the method described by Martins et al. (2007).

The concentrations of $\mathrm{Al}, \mathrm{Ca}, \mathrm{Ce}, \mathrm{Co}, \mathrm{La}, \mathrm{Sc}$ and Th were determined after complete digestion of the sediment, using 4 acids $\left(\mathrm{HClO}_{4}, \mathrm{HNO}_{3}, \mathrm{HCl}, \mathrm{HF}\right)$, followed by analysis by ICP-MS, at ACME Laboratory, Canada. The chemical concentrations of the elements were normalized by the $\mathrm{Al}$ $(\mathrm{Ca} / \mathrm{Al}, \mathrm{Ce} / \mathrm{Al}, \mathrm{Co} / \mathrm{Al}, \mathrm{La} / \mathrm{Al}, \mathrm{Sc} / \mathrm{Al}$ and $\mathrm{Th} / \mathrm{Al})$ and $\mathrm{Sc}$ $(\mathrm{Ce} / \mathrm{Sc}, \mathrm{Co} / \mathrm{Sc}, \mathrm{La} / \mathrm{Sc}$ and $\mathrm{Th} / \mathrm{Sc}$ ) contents. The $\mathrm{Co} / \mathrm{Th}$ ratio was also determined.

The age model of this core was established by Martins et al. (2013b). It was based on four radiocarbon dates from the following levels: $33-34 \mathrm{~cm}, 71-72 \mathrm{~cm}, 143-144 \mathrm{~cm}$, and 193$194 \mathrm{~cm}$. Radiocarbon analyses were performed in foraminifera tests (10 $\mathrm{mg}$ to $20 \mathrm{mg}$ of various species) with size $>125 \mu \mathrm{m}$. Analyses were performed at Beta Analytic Inc., Miami, Florida, USA, by AMS. This work employed radiocarbon calibrated (cal BP) ages ( $2 \sigma$ calibration) using the OxCal program v4.1.7 (Bronk Ramsey, 2001, 2008, 2009, 2010). Radiocarbon ages were not corrected for the reservoir effect, since they are quite variable in this region, for the late Holocene (Soares and Dias, 2007).

Before statistical analysis, data were logarithmically transformed by $\log (1+x)$. Pearson correlations between the studied variables were determined. A Principal Component Analysis (PCA) was applied to explain the variance of the main data and to display the general evolution of this core. 
Both these analyses were performed with Statistica 13.0 software. The study area was mapped using the Surfer 10 software.

\section{Results}

Results of radiocarbon data are presented in Table 1. Ages determined for the following levels were: $33-34 \mathrm{~cm}$ : 1160 to $970 \mathrm{cal} \mathrm{BP} ; 71-72 \mathrm{~cm}: 1610$ to $1420 \mathrm{cal} \mathrm{BP} ; 143-145$ $\mathrm{cm}$ : 2160 to $1980 \mathrm{cal} \mathrm{BP}$, and $193-194 \mathrm{~cm}: 2720$ to $2470 \mathrm{cal}$ BP. The age model of core KSGX 24 is shown in Figure 2. It allows the estimation of an age of approximately $3 \mathrm{ka} \mathrm{cal}$ $\mathrm{BP}$ for the core base. The mean sedimentation rate is quite variable along the core, and was estimated for the following sections: $0-34 \mathrm{~cm} \approx 30 \mathrm{~cm} / \mathrm{ka}, 35-72 \mathrm{~cm} \approx 90 \mathrm{~cm} / \mathrm{ka} ; 73-144$ $\mathrm{cm} \approx 82 \mathrm{~cm} / \mathrm{ka}$, and $144-235 \mathrm{~cm} \approx 122 \mathrm{~cm} / \mathrm{ka}$.

Core KSGX 24 is a muddy sedimentary sequence. The average sediment mean grain size is $19.4 \mu \mathrm{m}$ and varies between $13.4 \mu \mathrm{m}$ and $26.4 \mu \mathrm{m}$ (Fig. 3). The percentage of fines fraction oscillated between $76 \%$ and $91 \%$, and magnetic susceptibility (SI unities) varied between 0.14 and 0.49 SI (average: -0.26 SI) (Fig. 4).

Main sediment mineralogical composition includes (Fig. 3): phyllosilicates (max: $43.8 \%$, min.: $9.3 \%$, average: $23.8 \%$ ), quartz (max: $34.5 \%$, min.: $14.4 \%$, average: $23.5 \%$ ), Kfeldspars (max: $12.9 \%$, min.: $1.4 \%$, average: $5.0 \%$ ) and plagioclase (max: $17.2 \%$, min.: $4.8 \%$, average: $9.4 \%$ ). Sediment mineralogical composition also includes carbonates (max: $21.2 \%$, min.: $2.9 \%$, average: 10.8\%), siderite (max: $2.6 \%$, min.: $0.0 \%$, average: $1.2 \%$ ) and low occurrences of other minerals, such as opal $\mathrm{C} / \mathrm{T}$, anatase, dolomite and pyrite $(<6 \%)$.

The geochemical composition of the sediment revealed the following values for chemical elements analyzed in this work: $\mathrm{Al}(\max .8 .5 \%$, min. $5.4 \%$, average $6.4 \%)$; $\mathrm{Ca}(\max$. $6.0 \%$, min. $2.6 \%$, average 4.7\%); Ce (max. $96 \mathrm{mg} \mathrm{kg}-1$, min. $65 \mathrm{mg} \mathrm{kg}-1$, average $81 \mathrm{mg} \mathrm{kg}-1$ ); Co (max. $10.4 \mathrm{mg} \mathrm{kg}-1$, min. $5.9 \mathrm{mg} \mathrm{kg}-1$, average $7.8 \mathrm{mg} \mathrm{kg}-1$ ); La (max. $46 \mathrm{mg} \mathrm{kg-}$ 1, min. $28 \mathrm{mg} \mathrm{kg}-1$, average $38 \mathrm{mg} \mathrm{kg}-1$ ); Sc (max. $11.5 \mathrm{mg}$ $\mathrm{kg}-1$, min. $6.2 \mathrm{mg} \mathrm{kg}-1$, average $8.2 \mathrm{mg} \mathrm{kg}-1$ ), and $\mathrm{Th}$ (max. $18.7 \mathrm{mg} \mathrm{kg}-1$, min. $11.7 \mathrm{mg} \mathrm{kg}-1$, average $15.5 \mathrm{mg} \mathrm{kg}-1$ ).

The core data of $\mathrm{Al}$ content, as well as of $\mathrm{Ca} / \mathrm{Al}, \mathrm{Ce} / \mathrm{Al}$, $\mathrm{La} / \mathrm{Al}, \mathrm{Sc} / \mathrm{Al}$ and $\mathrm{Th} / \mathrm{Al}$ values, are presented in Figure 4. In this figure, these geochemical data are compared with the fine fraction content and magnetic susceptibility values.

In the finer grained sections, $\approx 134-90 \mathrm{~cm}$ and $\approx 26-0 \mathrm{~cm}$, several variables tend to increase, namely phyllosilicates (Fig. 3), magnetic susceptibility (Fig. 4), Al (Fig. 4), Co and Sc content, as well as $\mathrm{Co} / \mathrm{Al}, \mathrm{Co} / \mathrm{Th}$ and $\mathrm{Sc} / \mathrm{Al}$ values (Fig. 4). In these sections, the values of other variables, such as $\mathrm{K}$ feldspars (Fig. 3), $\mathrm{Ca} / \mathrm{Al}, \mathrm{Ce} / \mathrm{Al}, \mathrm{La} / \mathrm{Al}$ and $\mathrm{Th} / \mathrm{Al}$ (Fig. 4), as well as $\mathrm{Ce} / \mathrm{Sc}, \mathrm{La} / \mathrm{Sc}$ and $\mathrm{Th} / \mathrm{Sc}$, tend to decline.

\subsection{Statistical results}

The biplots presented in Figure 5 show the regression line and relatively high values of $\mathrm{R}^{2}$ for the following variables: $\mathrm{A}$ - $\mathrm{Ca}(\%)$ versus $\mathrm{Al}(\%)\left(\mathrm{R}^{2}=0.6176\right) ; \mathrm{B}$ - Sc (mg Kg-1) versus $\mathrm{Al}(\%)\left(\mathrm{R}^{2}=0.8231\right) ; \mathrm{C}-\mathrm{Ca}(\%)$ versus $\mathrm{Ce} / \mathrm{Al}\left(\mathrm{R}^{2}=0.6567\right)$; $\mathrm{D}$ - $\mathrm{Ca}(\%)$ versus $\mathrm{Co} / \mathrm{Th}\left(\mathrm{R}^{2}=0.6387\right) ; \mathrm{E}-\mathrm{Ca}(\%)$ versus $\mathrm{La} / \mathrm{Sc}\left(\mathrm{R}^{2}=0.7727\right)$, and $\mathrm{F}-\mathrm{Co} / \mathrm{Th}$ versus $\mathrm{Ce} / \mathrm{Al}\left(\mathrm{R}^{2}=\right.$ $0.6791)$.

Results of these biplots evidence the following positive correlations: $\mathrm{Sc}$ and $\mathrm{Al} ; \mathrm{Ca}$ and $\mathrm{Ce} / \mathrm{Al}$ and $\mathrm{La} / \mathrm{Sc}$. They also show that the following variables have negative correlations: $\mathrm{Ca}$ and $\mathrm{Al} ; \mathrm{Ca}$ and $\mathrm{Co} / \mathrm{Th}$ and; $\mathrm{Co} / \mathrm{Th}$ and $\mathrm{Ce} / \mathrm{Al}$.

Table 3 shows that there are significant correlations between most analyzed variables. In this table we can observe that, for instance, $\mathrm{Al}, \mathrm{Co}, \mathrm{Sc}, \mathrm{Co} / \mathrm{Al}, \mathrm{Co} / \mathrm{Th}, \mathrm{Sc} / \mathrm{Al}$, and $\mathrm{Sc} / \mathrm{Th}$ are significantly positively correlated with each other, and negatively correlated with $\mathrm{Ca}, \mathrm{Ca} / \mathrm{Al}, \mathrm{Ce}, \mathrm{Ce} / \mathrm{Al}$, $\mathrm{Ce} / \mathrm{Sc}, \mathrm{La}, \mathrm{La} / \mathrm{Al}, \mathrm{La} / \mathrm{Sc}, \mathrm{Th}, \mathrm{Th} / \mathrm{Al}$ and $\mathrm{Th} / \mathrm{Sc}$.

These correlations are clearly visualized in the groups established by Principal Components Analysis (PCA) for the first two factors, which explain 69\% of data variability (Fig. 6). In this PCA, the explained variability for the first and second factors is 0.60 and 0.10 , respectively.

The PCA establishes four groups of variables. Group I contains $\mathrm{Ca}(\%), \mathrm{Ce}\left(\mathrm{mg} \mathrm{kg}^{-1}\right)$, La $\left(\mathrm{mg} \mathrm{kg}^{-1}\right)$, Th $\left(\mathrm{mg} \mathrm{kg}^{-1}\right)$ and $\mathrm{K}$-feldspars (\%), as well as the ratios $\mathrm{Ca} / \mathrm{Al}, \mathrm{Ce} / \mathrm{Al}, \mathrm{Ce} / \mathrm{Sc}$, $\mathrm{La} / \mathrm{Al}, \mathrm{La} / \mathrm{Sc}, \mathrm{Th} / \mathrm{Al}$ and $\mathrm{Th} / \mathrm{Sc}$. These variables are positively correlated with Factor 1.

Group II of the PCA (Fig. 6) includes $\mathrm{Al}(\%), \mathrm{Co}$ (mg kg$\left.{ }^{1}\right)$, Sc $\left(\mathrm{mg} \mathrm{kg}^{-1}\right)$ and phyllosilicates (\%), as well as magnetic susceptibility (SI) and ratios $\mathrm{Co} / \mathrm{Al}, \mathrm{Co} / \mathrm{Th}$, and $\mathrm{Sc} / \mathrm{Al}$, and are negatively correlated with Factor 1. Group III is composed of quartz (\%) and plagioclase (\%). On the other hand, Group IV includes phyllosilicates (\%), anatase (\%) and $\mathrm{K}$-feldspars (\%).

The age plot of Factor Score 1 of the PCA of Figure 6 is presented in Figure 7. The results of Factor Score 1 were compared with $\mathrm{Th} / \mathrm{Sc}$ and $\mathrm{Co} / \mathrm{Th}$, which were selected from groups I and II, respectively, of the PCA of Fig. 5.

The pattern of evolution of the values of Factor Score 1 are similar to that of $\mathrm{Th} / \mathrm{Sc}$ and is the opposite of $\mathrm{Co} / \mathrm{Th}$. The lowest values of this Factor Score are coincident with 
major geochemical changes associated with the sections with finest grained sediments found in this core.

\section{Discussion}

\subsection{Sedimentological characteristics of Core KSGX 24}

Core KSGX 24 consists of a very fine sedimentary sequence, which potentially provides a continuous record of paleoclimate oscillations. It was collected in a relatively deep area of the external sector of Ria de Vigo, protected by the Cies Islands. It was recovered from an area of muddy sediments according to the recent sedimentary cover descriptions of Salgado (1993) and Vilas et al. (1995).

Garcia-Garcia et al. (2005) provides a longer overview of the sedimentary evolution of this system since $18 \mathrm{ky} \mathrm{BP} \mathrm{(last}$ glaciation). According to these authors, sediment grain size and composition in Ria de Vigo are mainly conditioned by the hydrodynamism. Consequently, sandy sediments appear close to the ria margins, where currents reach the highest speeds. The muddy sediments are located, preferentially, along the central axis of the ria, corresponding to the zone of greater depth. This area is less influenced by the waves and has slower currents along the bottom, enabling the deposition of muddy sediments.

The obstruction caused by the Cies Islands, in the external sector, also favors the deposition of fine sediments. According to Lantzsch et al. (2009), the accumulation of these muddy areas also was influenced by the mid Holocene deceleration of the sea-level rise. This phenomenon caused a rapid refill of the accommodation space within river valleys, and allowed the development of mud deposits in the Iberian continental shelf and in some transitional environments, such as that in Ria de Vigo.

Thus, based on the characteristics of particle size of this core, we can deduce that low hydrodynamic conditions prevailed in the last $3 \mathrm{ka}$ cal BP in the study area. However this core presents some variability in grain size. The sediments become finer, for instance, in sections $\approx 134-90$ $\mathrm{cm}$ and $\approx 26-0 \mathrm{~cm}$.

In these finer sections, geochemical and mineralogical changes also are recorded, as well as a slight increase in magnetic susceptibility. These grain size variations are indicative that the bottom hydrodynamical regime did not remain unchangeable in the study area.

Furthermore, changes in the mineralogical and geochemical composition of the sediments may be related to hydrodynamic factors, but may also be related to other kinds of alterations. For instance, the presence of pyrite (iron sulfide) and siderite (iron carbonate) in the composition of the sediments of core KSGX 24 indicates the possible occurrence of authigenic/ diagenetic processes in the study area.

Pyrite formation can be formed in anoxic sediments through diagenetic processes (Froelich et al., 1979; Wilkin and Bames, 1996, Neumann et al., 1997, Kastner, 1999). Siderite $\left(\mathrm{FeCO}_{3}\right)$ is a well-known authigenic mineral restricted to anoxic non-sulfidic methanic environments (Glasby and Schultz, 1999, and references therein). Both occur in areas where fine-grained and organic-rich sediments are rapidly accumulated and where $\mathrm{CO}_{2}$ is produced as a result of organic matter decomposition (Frederichs et al., 2003) mediated by biological processes (Nealson and Saffarini, 1994; Konhauser, 1998).

Organisms such as mollusks and foraminifera may contribute with their shells and tests with carbonates for sediment composition. The rocks crossed by the streams and rivers that discharge in the Ria de Vigo are poor in carbonates, and this is a common feature for most of the NW Iberian Peninsula lithology (Julivert et al., 1980).

Thus, sediments in the Rias Baixas are in general impoverished in carbonates (Prego et al., 2012). The sediment becomes rich in calcite off-rias, in the nearby continental shelf, where its content increases towards the continental slope (20-35\%, Prego et al., 2012). This is a common feature in the western Iberian continental shelf due to the biological contribution of bioclasts provided, mainly mollusks shells and foraminifera tests and the reduction of the dilution by lithogenic particles (Dias and Nittrouer, 1984; Martins et al., 2012, 2015b). Thus, whereas the $\mathrm{Al}$ is an essentially lithogenic element in this core, $\mathrm{Ca}$ is mostly a biogenic element. Thus, the $\mathrm{Ca} / \mathrm{Al}$ ratio can be seen as a proxy for the relative importance of the contribution in biogenic particles to the sediments of this study area. In the two main sections where the sediments are finer, $\approx 134-90$ $\mathrm{cm}$ and $\approx 26-0 \mathrm{~cm}$, the values of the $\mathrm{Ca} / \mathrm{Al}$ ratio clearly decrease (Fig. 4), which indicates a reduction in the biogenic component to the sediment. The possible causes of this reduction were discussed by Martins et al. (2013b). These authors, based on the characteristics of benthic foraminifera density and in the composition and structure of their assemblages, deduced that these changes were caused by a higher supply of organic matter, which led to disoxic conditions in the sedimentary environment.

Detrital minerals deposited in the study area are likely provided mainly by river runoff into the Ria de Vigo. Once in this system, the coarser particles were deposited near the river mouth and the finer ones were probably redistributed by the current circulation inside this system. But part of the detrital component that composes core KSGX 24 may also 
be supplied from nearby oceanic areas. Chemical elements, such as $\mathrm{Al}, \mathrm{Ce}, \mathrm{Co}, \mathrm{La}, \mathrm{Sc}$ and Th, may be related mostly with the detrital component of the sediments. Thus, the variability of these element concentrations may indicate changes in sediment composition related to the supply of the lithogenic component of the sediments.

Variations in the values of magnetic susceptibility (MS) indicate an increased concentration of magnetic minerals. However, XRD did not allow the identification of these minerals, since they are probably rare and their abundance may be below the detection capability of the XRD device.

Most of the magnetic susceptibility values are negative along core KSGX 24, which indicates that the magnetic materials are, in fact, not abundant in the study area. However this kind of minerals can be supplied from the weathering of igneous rocks, quite common in the study area and where the dominant magnetic minerals, such as magnetite and titanomagnetite minerals, exists.

The finer grained sections of core KSGX 24, $\approx 134-90 \mathrm{~cm}$ and $\approx 26-0 \mathrm{~cm}$, are marked by relatively high values of: detrital mineral content, including phyllosilicates (Fig. 3); magnetic susceptibility (Fig. 4); Al, Co and Sc content, and $\mathrm{Sc} / \mathrm{Al}$ (Fig. 4), $\mathrm{Co} / \mathrm{Al}$ and $\mathrm{Co} / \mathrm{Th}$. These sections also are characterized by the decline of $\mathrm{Ce}, \mathrm{La}$ and Th content and the decrease of Ce/Al (Fig. 4), Ce/Sc, La/Al (Fig. 4), La/Sc, $\mathrm{Th} / \mathrm{Al}$ (Fig. 4) and $\mathrm{Th} / \mathrm{Sc}$ values. The finer grained sections are also characterized by relatively low sedimentation rate, which indicates a lower deposition of sediments. The slight rise of magnetic susceptibility (MS) indicates a slight increase in magnetic mineral concentration in these sections. Aluminum concentrations have significant positive correlations with phyllosilicates, which are certainly a source of this chemical element. The relationship between $\mathrm{Al}$ and phyllosilicates was shown by several studies in the Iberian Margin (e.g. Araújo et al., 2002; Martins et al., 2013b). According to these studies, both $\mathrm{Al}$ and phyllosilicates generally increase in fine grained sediments.

In core KSGX 24, significant positive correlations between Sc and phyllosilicates also were found, which may indicate that these minerals may also be a source of Sc. In the Earth's crust, Sc is primarily a trace constituent of ferromagnesium minerals (amphibole-hornblende, biotite, and pyroxene) and in other minerals such as muscovite (Horowitz et al., 1975; Ford et al., 1993; Hedrick, 2010). Ferromagnesium minerals commonly occur in igneous rocks, which prevail in the continental region around the Ria de Vigo (Julivert et al., 1980).

Cobalt is intrinsically linked with deposit mineralogy (Mudd et al., 2013). It can occur mainly as independent minerals and preferentially concentrates in cobalt-bearing pyrite and pyrrhotite (Qingpeng et al., 2014). It is a sulphophile and siderophile element, and widely occurs in a variety of forms in many deposits (Qingpeng et al., 2014).

Elements such as Ce, La and Th are found in a number of minerals, the most important being the phosphate mineral monazite and bastnäsite, which are common in the weathering products of granitoid rocks and pegmatites. It is known that by their immobile nature during rock crystallization from the original magma, Ce, La and Th are preferentially concentrated in felsic rocks. Moreover Co and Sc reach in general highest concentrations in mafic and ultramafic rocks. These features turns the variability of these elements in siliciclastic sediments as potential provenance indicators (Taylor and McLennan, 1985; Bhatia and Crook, 1986).

The enrichment $\mathrm{Ce}, \mathrm{La}$, Th and $\mathrm{Ca}$ (also indicated by the higher values of $\mathrm{Ce} / \mathrm{Al}, \mathrm{Ce} / \mathrm{Sc}, \mathrm{La} / \mathrm{Sc}, \mathrm{La} / \mathrm{Al}, \mathrm{Th} / \mathrm{Al}$ and $\mathrm{Th} / \mathrm{Sc}$ ) is recorded mostly in the slightly coarser sections 220-190 cm and 130-30 cm. In these sections, the concentrations of $\mathrm{Co}$ and $\mathrm{Sc}$ (also indicated by the values of $\mathrm{Co} / \mathrm{Al}, \mathrm{Co} / \mathrm{Th}$ and $\mathrm{Sc} / \mathrm{Al}$ ratios) drop significantly.

The mineralogical and geochemical composition of core KSGX 24 also indicate that bottom hydrodynamical conditions have changed over the last $3 \mathrm{ka} \mathrm{cal} \mathrm{BP.} \mathrm{However,}$ the geochemical alterations along core KSGX 24 may not only be related to shifts in hydrodynamical forces, but also with alterations in current patterns, which favored the deposition of particles from different sediment sources.

The estimated sediment accumulation rate was highest in the core base, but presents a general decreasing trend from the bottom toward the top of core KSGX 24. However, sediment accumulation rate was relatively reduced in sections $185-135 \mathrm{~cm}$ and $25-0 \mathrm{~cm}$, where the concentrations of $\mathrm{Co}$ and Sc increase. These records may indicate not only changes in the current patterns and intensity, but also modifications in the rainfall regime, which affect the supply of sediments by the rivers to the Ria de Vigo, and are related to climatic changes.

Despite these climatic factors, which may have affected the deposition of sediments in the external sector of the Ria de Vigo, human influence cannot be ruled out on this system (Perez-Arlucea et al., 2005). The anthropogenic impacts in the last 3000 years was registered in several records related, for instance, to mining activities (Kylander et al., 2005), and changes in vegetation due to land use (Desprat et al., 2003; Martínez-Cortizas et al., 2005).

\subsection{The possible influence of climatic oscillations}

The geochemical records in core KSGX 24 suggest significant changes in sediment composition (Fig. 7). These 
changes were characterized, for instance, in the periods between $\approx 2.5-2.0 \mathrm{ka}$ cal BP and in the last $500 \mathrm{ka} \mathrm{cal} \mathrm{BP}$, by lower values of $\mathrm{Th} / \mathrm{Sc}$ (but also $\mathrm{Ce} / \mathrm{Sc}$ and $\mathrm{La} / \mathrm{Sc}$ ) and higher values of Co/Th. According to Martins et al. (2013b), this period was characterized by high supply of organic matter to the sediments, probably linked with reinforced northerly winds and the prevalence of a stronger upwelling regime. These characteristics may be associated with positive NAO phases (Oschlies, 2001).

Climatic oscillations may also have induced alterations in the circulation pattern in the nearby continental shelf, in the Iberian upwelling system and in oceanic productivity during the late Holocene (Álvarez et al., 2005; Bartels-Jónsdóttir et al., 2006, Lebreiro et al., 2006). Other studies performed in Ria de Vigo also indicate changes in biological productivity in this system related to the prevalence of stronger upwelling for relatively long periods (Diz et al., 2002; Álvarez et al., 2005).

According to our interpretations, the layers enriched in Co and Sc, associated with lower sedimentation rates and finer grained sediments, may denote a tendency for relative dryness, lower bottom hydrodynamism and a deposition of materials provided mainly from inner areas of the Ria de Vigo. Some rivers that discharge into this system cross areas where there are nuclei of mafic and ultramafic rocks (Julivert et al., 1980). The erosion of these outcrops may be a source of these elements. The concentrations of $\mathrm{Co}$ and $\mathrm{Sc}$ can become more significant when they are being less diluted by other lithogenic materials richer in other elements, namely $\mathrm{Ce}, \mathrm{La}$ and Th.

The periods between $\approx 3.0-2.5 \mathrm{ka}$ cal BP and $\approx 1.5-1.0 \mathrm{ka}$ cal BP are characterized by the highest values of Th/Sc (Fig. 7), but also $\mathrm{Ce} / \mathrm{Sc}$ and $\mathrm{La} / \mathrm{Sc}$ (Fig. 6). Relatively coarse sediments and high sedimentation rates (Figs. 3, 4) may be related to a bottom regime relatively more hydrodynamic, but also to a higher supply of sediments to the study area. These sedimentary characteristics may be linked with a rainier period and/or a higher contribution of materials from the nearby continental shelf.

The increase of K-feldspars along with Th/Sc, Ce/Sc and $\mathrm{La} / \mathrm{Sc}$ may indicate a supply of sediment from relatively close source areas, since the K-feldspars are one of the more readily alterable minerals. These materials are mostly provided from the erosion of felsic rocks, which are more common in the NW Iberian Peninsula continental areas. These regions are crossed by most of the rivers and streams that discharge sediments in the Ria de Vigo or by rivers from north Portugal.

The materials supplied by these rivers to the northern Portuguese continental shelf are remobilized by waves and currents and transported northward, feeding the sedimentary deposits of the Galician continental shelf under the winter oceanographic regime. These processes are well described by Dias et al. (2002a, b). Fine sedimentary materials resuspended from coastal oceanic areas may enter the Ria de Vigo and be deposited in the outer sector of this system.

\section{Conclusions}

The fine sedimentary sequence that comprises core KSGX 24 evidences that in the last $3 \mathrm{ka}$ a weak bottom hydrodynamic regime prevailed in the study area. However, changes in the sediment grain size, and mineralogical and geochemical composition, indicate that the hydrodynamic conditions have changed over that period.

These changes may be related to variations in the pattern of prevailing winds and rainfall regime, linked to the NAO variability, according to a longer pattern than the current one, which displays a decadal tendency. Climate oscillations seem to have left a fingerprint in the sediment characteristics of the outer sector of Ria de Vigo in the last $3 \mathrm{ka}$ cal BP.

But the influence of other factors cannot be discarded in the sediment grain size, and in the mineralogical and geochemical evolution in core KSGX 24, which may include: authigenetic and diagenetic reactions; the tendency for sea level rise; and lastly, anthropogenic influences in nearby continental areas.

\section{Acknowledgments}

The authors wish to thank Cleveland Jones for the manuscript proofreading. This paper is a contribution of the European OMEX project. It was partially financed through UID/GEO/04035/2013 (FCT, Portugal).

\section{References}

Abrantes, F., Lebreiro, S., Rodrigues, T., Gil, I., Bartels-Jónsdóttir, H., Oliveira, P., Kissel, C., Grimalt, J.O., 2005. Shallow-marine sediment cores record climate variability and earthquake activity off Lisbon (Portugal) for the last 2000 years. Quaternary Science Reviews 24, 2477-2494.

Abrantes, F., 1991. Increased upwelling off Portugal during the last glaciation: diatom evidence. Marine Micropaleontology 17, 285-310.

Álvarez, M.C., Flores, J.A., Sierro, F.J., Diz, P., Francés, G., Pelejero, C., Grimalt, J., 2005. Millennial surface water dynamics in the Ría de Vigo during the last 3000 years as revealed by coccoliths and molecular biomarkers. Palaeogeography, Palaeoclimatology, Palaeoecology 218, 1-13.

Álvarez-Salgado, X.A., Rosón, G., Pérez, F.F., Figueiras, F.G., Pazos, Y., 1996. Nitrogen cycling in an estuarine upwelling system, the Ria de Arousa NW Spain: I. Short-time-scale 
patterns of hydrodynamic and biogeochemical circulation. Marine Ecology Progress Series 135, 259-273.

Álvarez-Salgado, X.A., Rosón, G., Pérez, F.F., Pazos, Y., 1993. Hydrographic variability off the Rías Baixas (NW Spain) during the upwelling season. Journal of Geophysical Research 98, 14447-14455.

Araújo, M.F., Corredeira, C., Gouveia, A., 2007. Distribution of the rare earth elements in sediments of the Northwestern Iberian Continental Shelf. Journal of Radioanalytical and Nuclear Chemistry 271, 255-260.

Araújo, M.F., Jounneau, J.-M., Valério, P., Barbosa, T., Gouveia, A., Oliveira, A., Rodrigues A., Dias, J.M.A., 2002. Geochemical tracers of northern Portuguese estuarine sediments on the shelf. Progress in Oceanography 52, 277-297.

Astakhov, A.S., Beloglazov, A.I., Mozherovsky, A.V., 1995. Mineral-geochemical association in bottom sediments of the East China Sea. TAO 6, 91-102.

Baas, J.H., Mienert, J., Abrantes, F., Prins, M.A., 1997. Late Quaternary sedimentation on the Portuguese continental margin: climate-related processes and products. Palaeogeography, Palaeoclimatology, Palaeoecology 130, 1-23.

Bartels-Jónsdóttir, H.B., Knudsen, K.L., Abrantes, F., Lebreiro, S., Eiríksson, J., 2006. Climate variability during the last 2000 years in the Tagus Prodelta, western Iberian Margin: benthic foraminifera and stable isotopes. Marine Micropaleontology 59, 83-103.

Bernárdez, P., González-Álvarez, R., Francés, G., Prego, R., Bárcena M.A., Romero, O.E., 2008. Late Holocene history of the rainfall in the NW Iberian peninsula - Evidence from a marine record. Journal of Marine Systems 72, 366-382.

Bhatia, M.R., Crook, K.A.W., 1986. Trace element characteristics of greywackes and tectonic setting discrimination of sedimentary basin. Contributions to Mineralogy and Petrology 92, 181-193.

Bianchi, G.G., McCave, I.N., 1999. Holocene periodicity in North Atlantic climate and deep-ocean flow south of Iceland. Nature 397, 515-517.

Bischoff, J.L., Cummins, K., 2001. Wisconsin glaciation of the Sierra Nevada (79,000-15,000 yr B.P.) as recorded by rock flour in sediments of Owens Lake, California. Quaternary Research 55, 14-24.

Bischoff, J.L., Menking, K.M., Fitts, J.P., Fitzpatrick, J.A., 1997. Climatic oscillations 10,000-155,000 yr B.P. at Owens Lake, California reflected in glacial rock flour abundance and lake salinity in core OL-92. Quaternary Research 48, 313-325.

Blanton, O., Tenore, K.R., Castillejo, F., Atkinson, L.P., Schwing, F.P., Lavin, A., 1987. The relationship of upwelling to mussel production in the rias on the Western coast of Spain. Journal of Marine Research 45, 495-511.

Bond, G., Showers, W., Cheseby, M., Lotti, R., Almasi, P., deMenocal, P., Proire, P., Cullen, H., Hajdas, I., Bonani, G., 1997. A pervasive millennial-scale cycle in North Atlantic Holocene and glacial climates. Science 278, 1257-1266.

Bronk Ramsey, C., 2001. Development of the radiocarbon calibration program OxCal. Radiocarbon 43 (2A), 355-363.
Bronk Ramsey, C., 2008. Deposition models for chronological records. Quaternary Science Reviews 27 (1-2), 42-60.

Bronk Ramsey, C., 2009. Bayesian analysis of radiocarbon dates. Radiocarbon 51(1), 337-360.

Bronk Ramsey, C., 2010. OxCal v4.1.7 (https://c14.arch.ox.ac.uk/login/login.php?Location=/oxcal /OxCal.html

Caetano, M., Prego, R., Vale, C., de Pablo, H., MarmolejoRodríguez, J., 2009. Evidence for early diagenesis of rare earth elements and metals in a transition sedimentary environment. Marine Chemistry 116, 36-46.

Chen, H.-F., Chang, Y.-P., Kao, S.-J., Chen, M.-T., Song, S.-R., Kuo, L.-W., Wen, S.-Y., Yang, T.-N., Lee, T.-Q., 2011. Mineralogical and geochemical investigations of sedimentsource region changes in the Okinawa Trough during the past $100 \mathrm{ka}$ (IMAGES core MD012404). Journal of Asian Earth Sciences 40, 1238-1249.

Crowley, S.E., Stow, D.A.V., Croudace, I.W., 1998. Mineralogy and geochemistry of Bay of Bengal deep-sea fan sediments, ODP Leg 116: evidence for an Indian subcontinent contribution to distal fan sedimentation. In: Cramp, A., Macleod, C.J., Lee, S. V., Jones, E.J.W. (eds.), Geological Evolution of Ocean Basins: Results from the Ocean Drilling Program, Geological Society of London Special Publication 131, pp. 151-176.

Cullers, R.L., Berendsen, P., 1998. The provenance and chemical variation of sandstones associated with the Mid-continent Rift System, USA. European Journal of Mineralogy 10, 987-1002.

Cullers, R.L., Stone, J., 1991. Chemical and mineralogical comparison of the Pennsylvanian Fountain Formation, Colorado, USA an uplifted continental block to sedimentary rocks from other tectonic environments. Lithos 27, 115-131.

Cullers, R.L., Basu, A., Suttner, L., 1988. Geochemical signature of provenance in sand-size material in soils and stream sediments near the Tobacco Root batholite, Montana, USA. Chemical Geology 70, 335-348.

Cullers, R.L., Barret, T., Carlson, R., Robinson, B., 1987. Rareearth element and mineralogical changes in Holocene soil and stream sediment: a case study in the Wet Mountains, Colorado, USA. Chemical Geology 63, 275-295.

Cullers, R.L., Chaudhuri, S., Kilbane, N., Koch, R., 1979. Rare earths in size fractions and sedimentary rocks of Pennsylvanian-Permian age from the mid-continent of the USA. Geochimica Cosmochimica Acta 43, 1285-1301.

deMenocal, P., Ortiz, J., Guilderson, T., Sarnthein, M., 2000. Coherent high and low-latitude climate variability during the Holocene warm period. Science 288, 2198-2202.

Desprat, S., Sánchez-Goñi, M.F., Loutre, M.F., 2003. Revealing climatic variability of the last three millennia in northwestern Iberia using pollen influx data. Earth Planetary Science Letters 213, 63-78. doi:10.1016/S0012-821X(03)00292-9.

Dias, J.M.A., Jouanneau, J.-M., Gonzalez, R., Araújo, M.F., Drago, T., Garcia, C., Oliveira, A., Rodrigues, A., Vitorino, J., Weber, O., 2002 a. Present day sedimentary processes on the northern Iberian shelf. Progress in Oceanography 52, 249-259. 
Dias, J.M.A., Gonzalez, R., Garcia, C., Diaz-del-Rio, V., 2002 b. Sediment distribution patterns on the Galicia-Minho continental shelf. Progress in Oceanography 52, 215-231.

Dias, J. M. A., Nittrouer, C., 1984. Continental shelf sediments of northern Portugal. Continental Shelf Research 3, 147-165.

Dickinson, W.R., Suczek, C.A., 1979. Plate tectonics and sandstone compositions. American Association of Petroleum Geologists Bulletin 63, 2164-2182.

Diekmann, B., Hofmann, J. Henrich, R., Futterer, D.K., Rohl, U., Kuo-Yen, W., 2008. Detrital sediment supply in the southern Okinawa Trough and its relation to sea-level and Kuroshio dynamics during the late Quaternary. Marine Geology 255, 8395.

Diz, P., Francés, G., Pelejero, C., Grimalt, J.O., Vilas, F., 2002. The last 3000 years in the Ría de Vigo (NW Iberian Margin): climatic and hydrographic signals. Holocene 12, 459-468.

Duplaix, S., Nesterofl, W.D., Heezen, B.C., 1965. Mineralogie comparee des sediments du Tage (Portugal) et de quelque sables profonds de la plaine abyssale correspondante. DeepSea Research 12, 211-217.

Fedo, C.M., Eriksson, K.A., Krogstad, E.J., 1996. Geochemistry of shales from the Archean ( $3.0 \mathrm{Ga})$ Buhwa Greenstone Belt, Zimbabwe: Implications for provenance and source-area weathering. Geochimica et Cosmochimica Acta 60, 1751-1763.

Figueiras, F.G., Labarta, U., Fernandez Reiriz, M.J., 2002. Coastal upwelling, primary production and mussel growth in the Rias Baixas of Galicia. Hydrobiologia 484, 121-131.

Fiuza, A., Macedo, M.E., Guerreiro, M.R., 1982. Climatological space and time variation of the Portuguese coastal upwelling. Oceanologica Acta 5, 31-40.

Ford, Eugene E., Scott D. Birmingham, Francesco Demartin, Tullio Pilati, Carlo M. Gramaccioli, and Frederick E. Lichte, 1993. Thortveitite and associated Sc-bearing minerals from Ravalli County, Montana. Canadian Mineralogist 31, 337-346.

Frederichs, T., von Dobeneck, T., Bleil, U., Dekkers, M.J., 2003. Towards the identification of siderite, rhodochrosite, and vivianite in sediments by their low-temperature magnetic properties. Physics and Chemistry of the Earth 28, 669-679.

Froelich, P.N., Klinkhammer, G.P., Bender, M.L., Luedtke, N.A., Heath, G.R., Cullen, D., Dauphin, P., Hammond, D., Hartman, B., Maynard, V., 1979. Early oxidation of organic matter in pelagic sediments of the Eastern Equatorial Atlantic: Suboxic diagenesis. Geochimica et Cosmochimica Acta 43, 1075-1090.

Garcia-Garcia, A., Garcia-Gil, S., Vilas, F., 2005. Quaternary evolution of the Ria de Vigo, Spain. Marine Geology 220, 153179.

García-Gil, S., Nombela, M.A., Alejo, I., Pazos, O., Rubio, B., García-Gil, E., Vilas, F., 1995. Dominios y Distribución de Facies en la Ría de Vigo. Reunión Monográfica Sobre El Cambio de la Costa: Los Sistemas de Rías. Universidad de Vigo, Vigo.

Gil, I.M., Abrantes, F., Hebbeln, D., 2006. The North Atlantic Oscillation forcing through the last 2000 years: spatial variability as revealed by high-resolution marine diatom records from N and SW Europe. Maine Micropaleontology 60, 113129.

Glasby, G.P., Schultz, H.D., 1999. EH, pH diagrams for Mn, Fe, $\mathrm{Co}, \mathrm{Ni}, \mathrm{Cu}$ and $\mathrm{As}$ under seawater conditions: applications of two new types of $\mathrm{Eh}, \mathrm{pH}$ diagrams to the study of specific problems in marine geochemistry. Aquatic Geochemistry 5, 227-248.

Gonthier, E.G., Faugeres, J.C., Stow, D.A.V., 1984. Contourite facies of the Faro Drift, Gulf of Cadiz. Spececial Publication Geological Society 15, 275-292.

González-Álvarez, R., Bernárdez, P., Pena, L.D., Francés, G., Prego, R., Diz, P., Vilas, F., 2005. Paleoclimatic evolution of the Galician continental shelf (NW of Spain) during the last 3,000 years: From a storm regime to present conditions. Journal of Marine System 54, 245-260.

Gu, X.X., Liu, J.M., Zheng, M.H., 2002. Provenance and tectonic setting of the Proterozoic turbidites in Hunan, South China: Geochemical Evidence. Journal of Sedimentary Research 72, 393-407.

Haynes, R., Barton, E.D., 1990. A poleward flow along the Atlantic coast of the Iberian Peninsula. Journal of Geophysical Research 95, 11425-11441.

Hedrick, J.B., 2010. Scandium. In Mineral commodity summaries 2010, U.S. Geological Survey, p. 140-141.

Horowitz, C.T. (Ed.), 1975. Scandium its occurrence, chemistry, physics, metallurgy, biology, and technology: Academic Press, New York, 598 p.

Hurrell, J.W., 1995. Decadal trends in the North Atlantic Oscillation: regional temperatures and precipitation. Science 269, 676-679.

Jason, R., Price, J.R., Velbel, M.A., Patino, L.C., 2005. Rates and time scales of clay-mineral formation by weathering in saprolitic regoliths of the southern Appalachians from geochemical mass balance. Bulletin of the Geological Society of America 117, 783-794.

Jouanneau, J.-M., Weber, O., Drago, T., Rodrigues, A., Oliveira, A., Dias, J.M.A., Garcia, C., Schmidt, S., Reyss, J.L., 2002. Recent sedimentation and sedimentary budgets on the western Iberian shelf. Progress in Oceanography 52, 261-275.

Julivert, M., Fontbote, J.M., Ribeiro, A., Conde, L., 1980. Mapa tectonico de la Península Ibérica y Baleares (scale 1/1 000 000) - explicative memory. Institute Geologico y Geominero de España, Madrid.

Kastner, M., 1999. Oceanic minerals: Their origin, nature of their environment, and significance. In National Academy of Sciences colloquium "Geology, Mineralogy, and Human Welfare", 1998. PNAS on line, 96, 3380-3387.

Konhauser, K.O., 1998. Diversity of bacterial iron mineralization. Earth Science Review 43, 91-121.

Kudrass, H.R., 1993. SONNE CRUISE SO-75-3: Cruise Report 1992. Test of the geological equipment by surveying and sampling of the southwestern Portuguese continental slope and the Ampere seamount. Bundesanst. Geowiss. Rohstoffe, Hannover, Rep. MFG 00947. 
Kudrass, H.-R., 1973. Sedimentation am Kontinentalhang vor Portugal und Marokko im Spiitpleistozfin und Holoz/in. Meteor-Forschungsergeb, Reihe C 13, 1-63. Kylander, M.E., Weiss, D.J., Martínez-Cortizas, A., Spiro, B., GarcíaSánchez, R., Coles, B.J., 2005. Refining the pre-industrial atmospheric $\mathrm{Pb}$ isotope evolution curve in Europe using an 8000 year old peat core from NW Spain. Earth Planetary Science Letters 240, 467-485.

Lantzsch, H., Hanebuth, T.J.J., Bender, V.B., 2009. Holocene evolution of mud depocentres on a high-energy, lowaccumulation shelf (NW Iberia). Quaternary Research 72, 325336.

Lebreiro, S.M., Francés, G., Abrantes, F.F.G., Diz, P., BartelsJónsdóttir, H.B., Stroynowski, Z., Gil, I.M., Pena, L.D., Rodrigues, T., Jones, P.D., Nombela, M.A., Alejo, I., Briffa, K.R., Harris, I., Grimalt, J.O., 2006. Climate change and coastal hydrographic response along the Atlantic Iberian margin (Tagus Prodelta and Muros Ría) during the last two millennia. Holocene 16, 1003-1015.

Lebreiro, S.M., Moreno, J.C., McCave, I.N., Weaver, P.P.E., 1996. Evidence for Heinrich layers off Portugal (Tore Seamount: 39N, 12W). Marine Geology 131, 47-56.

Martínez-Cortizas, A., Pontevedra-Pombal, X., García-Rodeja, E., Nóvoa-Muñoz, J.C., Shotyk, W., 1999. Mercury in a Spanish peat bog archive of climate change and atmospheric metal deposition. Science 284, 939-942.

Martínez-Cortizas, A.M., Mighall, T., Pombal, X.P., Munoz, J.C.N., Varela, E.P., Rebolo, R.P., 2005. Linking changes in atmospheric dust deposition, vegetation change and human activities in northwest Spain during the last 5300 years. Holocene 15, 698-706.

Martins, M.V.A., Perretti, A.R., Salgueiro, E., Frontalini, F., Moreno, J., Soares, A.M., Mahiques, M., Silva, de Azevedo, C.A., Alveirinho Dias, J.M.A., 2015a. Atlantic Sea Surface Temperatures Estimated from Planktonic Foraminifera Off the Iberian Margin Over the Last $40 \mathrm{Ka}$ BP. Marine Geology 367, 191-201. http://dx.doi:10.1016/j.margeo.2015.06.001

Martins, M.V.A., Victor Quintino, V., Tentúgal, R.M., Frontalini, F., Miranda, P., Laut, L.L.M., Martins, R., Rodrigues, A.M., 2015b. Characterization of bottom hydrodynamic conditions on the central western Portuguese continental shelf based on benthic foraminifera and sedimentary parameters Marine Environmental Research 109, 52-68. http://dx.doi.org/10.1016/j.marenvres.2015.06.006

Martins, V., Santos, J.F., Mackensen, A., Dias, J.M., Ribeiro, S., Moreno, J., Soares, A.M., Frontalini, F., Rey, D., Rocha, F., 2013a. The sources of the glacial IRD in the NW Iberian Continental Margin over the last $40 \mathrm{ka}$. Quaternary International, 318, 128-138. http://dx.doi 10.1016/j.quaint.2013.08.026.

Martins, V., Rocha, F., Sequeira, C., Martins, P., Santos, J., Dias, J.A., Weber, O., Jouanneau, J.-M., Rubio, B., Rey, D., Bernabeu, A., Silva, E., Laut, L., Figueira, R., 2013b. Late Holocene climatic oscillations traced by clay mineral assemblages and other paleoceanographic proxies in Ria de
Vigo (NW Spain). Turkish Journal of Earth Sciences 22, 398 413. http://dx.doi:10.3906/yer-1112-12.

Martins, V., Abrantes, I., Grangeia, C., Martins, P., Nagai, R., Sousa, S.H.M., Laut, L.L.M., Dias, J.M. A., Dias, J.M., Ferreira, E., Rocha, F., 2012. Records of sedimentary dynamics in the continental shelf and upper slope between Aveiro-Espinho (N Portugal). Journal of Marine Systems 96, 48-60, http:/ /dx.doi: 10.1016/j.jmarsys.2012.02.001.

Martins, V., Dubert, J., Jouanneau, J.-M., Weber, O., Silva, E.F., Patinha, C., Alveirinho Dias, J.M., Rocha, F., 2007. A multiproxy approach of the Holocene evolution of shelf-slope circulation on the NW Iberian Continental Shelf. Marine Geology 239, 1-18. http://dx.doi.org/10.1016/j.margeo.2006.11.001

Martins, V., Jouanneau, J.-M., Weber, O., Rocha, F., 2006 a. Tracing the late Holocene evolution of the NW Iberian upwelling system. Marine Micropaleontology 59, 35-55. doi:10.1016/j.marmicro.2005.12.002.

Martins, V., Patinha, C., Ferreira Da Silva, E., Jouanneau, J.-M., Weber, O., Rocha, F., 2006b. Holocene record of productivity in the NW Iberian continental shelf. Journal of Geochemical Exploration 88, 408-411.

Martins, V., Rocha, F., Gomes, C., Gomes, V., Jouanneau, J.-M., Weber, O., Dias, J., 2005. Geochemical, textural, mineralogical and micropaleontological data used for climatic reconstruction during the Holocene in the Galician sector of the Iberian continental margin. Ciencias Mariñas 31, 293-308.

Mayewski, P.A., Rohling, E.E., Stager, J.C., Karlén, W., Maasch, K.A., Meeker, L.D., Meyerson, E.A., Gasse, F., van Kreveld, S., Holmgren, K., Lee-Thorp, J., Rosqvist, G., Rack, F., Staubwasser, M., Schneider, R.R., Steig, E.J., 2004. Holocene climate variability. Quaternary Research 62, 243-255.

McLennan, S., Hemming, S., McDaniel, D., Hanson, G., 1993. Geochemical approaches to sedimentation, provenance, and tectonics. Geological Society of America Special Papers 284, 21-40.

McLennan, S., Taylor, S.R., 1991. Sedimentary rocks and crustal evolution: tectonic setting and secular trends. Journal of Geology 8, 1-21.

McLennan, S.M., 1989. Rare earth elements in sedimentary rocks: influence of provenance and sedimentary processes. Reviews in Mineralogy and Geochemistry, 21, 169-200.

Meese, D.A., Gow, A.J., Grootes, P., Mayewski, P.A., Ram, M., Stuiver, M., Taylor, K.C., Waddington, E.D., Zielinski, G.A., 1994. The accumulation record from the GISP2 core as an indicator of climate change throughout the Holocene. Science 266, 1680-1682.

Monteiro, J.H., Dias, J.A., Gaspar, L.C., Possolo, A.M., 1980. Recent marine sediments of the Portuguese continental shelf. Actual problems of oceanography in Portugal. Lisbon, pp. 8996.

Monteiro, J.H., Moita, I.M., 1971. Morfologia e sedimentos da plataforma continental e vertente continental superior ao largo da Península de Setúbal. I Congresso Hispano-LusoAmericano Geologia Económica, Madrid and Lisbon, pp. 301330. 
Mudd, G.M., Weng, Z., Jowitt, S.M., Turnbull, I.D., Graedel, T.E., 2013. Quantifying the recoverable resources of by-product metals: The case of cobalt. Ore Geology Reviews 55, 87-98.

Nealson, K.H., Saffarini, D., 1994. Iron and manganese in anaerobic respiration: environmental significance, physiology, and regulation. Annual Review Microbiology 48, 311-343.

Neumann, T., Christiansen, C., Clasen, S., Emeis, K.C., Kunzendorf, H., 1997. Geochemical records of salt-water inflows into the deeps of the Baltic Sea. Continental Shelf Research 17, 95-115.

O'Brien, S.R., Mayewski, P.A., Meeker, L.D., Meese, D.A., Twickler, M.S., Whitlow, S.I., 1995. Complexity of Holocene climate as reconstructed from a Greenland ice core. Science 270, 1962-1964.

Oliveira, A., Rocha, F., Rodrigues, A., Jouanneau, J.-M., Dias, A., Weber, O., Gomes, C., 2002. Clay minerals from the sedimentary cover from Northwest Iberian shelf. Progress in Oceanography 52, 233-247.

Ortega, L.A., Gil-Ibarguchi, J.I., 1990. The genesis of Late Hercynian granitoids from Galicia (northwestern Spain): inferences from REE studies. The Journal of Geology 98, 189-211.

Oschlies, A., 2001. NAO-induced long-term changes in nutrient supply to the surface waters of the North Atlantic. Geophysical Research Letters 28 (9), 1751-1754.

Peliz, A., Rosa, T.L., Miguel, A., Santos, P., Pissarra, J.L., 2002. Fronts, jets, and counter-flows in the Western Iberian upwelling system. Journal of Marine Systems 35, 61-77.

Perez-Arlucea, M., Mendez, G., Clemente, F., Nombela, M., Rubio, B., Figueira, M., 2005. Hydrology, sediment yield, erosion and sedimentation rates in the estuarine environment of the Ria de Vigo, Galicia, Spain. Journal of Marine Systems 54, 209-226.

Pin, C., Paquete, J.L., Santos-Zalduegui, J.F., Gil-Ibarguchi, J.I., 2002. Early Devonian suprasubduction-zone ophiolite related to incipient collisional processes in the Western Variscan Belt: the Sierra de Careón Unit, Ordenes Complex, Galicia. Geological Society of America Bulletin 364, 57-71.

Prego, R., Caetano, M., Bernardez, P., Brito, P., Ospina-Alvarez, N., Vale, C., 2012. Rare earth elements in coastal sediments of the Northern Galician Shelf: influence of geological features. Continental Shelf Research 35, 75-85.

Prego, R., 1993. General aspects of carbon biogeochemistry in the Ria de Vigo, northwestern Spain. Geochimica et Cosmochimica Acta 57, 2041-2052.

Qingpeng, M., Fengmei, C., Fang X., Yunhui, Y., 2014. Occurrence Forms and Distribution of Cobalt in Cihai Fe (-Co) Deposit, Xinjiang. Acta Geologica Sinica 88 (supp. 2), 304-305.

Salgado, R.J., 1993. Relación morfosedimentaria entre la plataforma continental de Galicia y las Rías Bajas y su evolución durante el Cuaternario. Publicaciones Especiales, Instituto Español de Oceanografía, Madrid, 17, 233 pp.

Schieber, J., 1992. A combined petrographical-geochemical provenance study of the Newland Formation, Mid-Proterozoic of Montana. Geological Magazine 129, 223-237.
Schönfeld, J., 1996. The impact of the Mediterranean Outflow Water (MOW) on benthic foraminiferal assemblages and surface sediments at the southern Portuguese continental margin. Marine Micropaleontology 29, 211-236.

Siedler, G., Seibold, E., 1974. Currents related to sediment transport at the Ibero-Moroccean continental shelf. MeteorForschungsergeb, Reihe A, 14, 1-12.

Soares, A.M.M., Dias, J.M.A., 2007. Reservoir effect of coastal waters off Western and Northwestern Galicia. Radiocarbon 49, 925-936.

Stow, D.A.V., Faugéres, J.-C., Gonthier, E., 1986. Facies distribution and textural variation in Faro Drift contourites: velocity fluctuation and drift growth. Marine Geology 72, 71100.

Tao, H., Wang, Q., Yang, X., Jiang, L., 2013. Provenance and tectonic setting of Late Carboniferous clastic rocks in West Junggar, Xinjiang, China: A case from the Hala-alat Mountains. Journal of Asian Earth Sciences 64, 210-222.

Taylor, S.M., McLennan S.M., 1985. The Continental Crust: Its Composition and Evolution, Blackwell Scientific Publications, Great Britain, p. 312.

Tenore, K.R., Alonso-Noval, M., Alvarez-Ossorio, M., Atkinson, L.P., Cabanas, J.M., Cal, R.M., Campos, H.J., Castillejo, F., Chesney, E.J., Gonzalez, N., Hanson, R.B., Mcclain, C.R., Miranda, A., Roman, M.R., Sanchez, J., Santiago, G., Valdes, L., Varela, M., Yoder, J., 1995. Fisheries and oceanography off Galicia, NW Spain: mesoscale spatial and temporal changes in physical processes and resultant patterns of biological productivity. Journal of Geophysical Research 100 (C6), 10943-10966.

Thamban, M., Rao, P.V., Schneider, R.R., 2002. Reconstruction of late Quaternary monsoon oscillations based on clay mineral proxies using sediment cores from the western margin of India. Marine Geology 186, 527-539.

Thiede, J., 1977. Aspects of the variability of the glacial and interglacial North Atlantic eastern boundary current (last 150.000 years). Meteor-Forschungsergeb, Reihe C, 28, 1-36.

Thorndycraft, V.R., Benito, G., 2006. The Holocene fluvial chronology of Spain: evidence from a newly compiled radiocarbon database. Quaternary Science Reviews 25, 223 234.

Torre, E., 1958. Estado actual del conocimiento de las Rias gallegas. In: Otero Pedrayo, R. (Ed.), Homenaje a Otero Pedrayo. Galaxia, Vigo, 237-250.

Trigo, R., Pozo-Vázquez, D., Osborn, T., Castro-Diez, Y., GanizFortis, S., Esteban-Parra, M.J., 2004. North Atlantic Oscillation influence on precipitation, river flow and water resources in the Iberian Peninsula. International Journal of Climatology 24, 925-944.

Underwood, M.B., Pickering, K., Gieskes, J.M., Kastner, M., Orr, R., 1993. Sediment geochemistry, clay mineralogy and diagenesis: a synthesis of data from Leg 131 of the Ocean Drilling Program, Nankai Trough. Proceedings of the Ocean Drilling Program, Scientific Results 131, 343-363. 
Vanney, J.R., Mougenot, D., 1990. Un canyon sous-marin du type "golf": le Canhão da Nazaré (Portugal). Oceanolologica Acta $13,1-14$.

Vicente-Serrano, M., Heredia-Laclaustra, A., 2004. NAO influence on NDVI trends in the Iberian Peninsula (1982-2000). International Journal of Remote Sensing 25 (14), 2871-2879.

Vidal Romani, J.R., 1984. A orixe das Rias Galegas. Estado da cuestion (1986-1983). Cuadernos da Area de Ciencias Marinas de Estudos Galegos 1, 13-25.

Vilas, F., Nombela, M.A., García-Gil, E., García-Gil, S., Alejo, I., Rubio, B., Pazos, O., 1995. Cartografía de sedimentos submarinos. Ría de Vigo. Xunta de Galicia, Consellería de Pesca, Marisqueo e Acuicultura. Vigo.

Wilkin, R.T., Bames, H.L., 1996. Pyrite formation by reactions of iron monosulfides with dissolved inorganic and organic sulphur species. Geochimica, Cosmochimica Acta 60, 41674179.

Yuretich, R., Ervin, C., 2002. Clay minerals as paleoenvironmental indicators in two large lakes of the African rift valleys: Lake Malawi and Lake Turkana. In: Renaut, R.W. and Ashley, G.M. (Eds.), Sedimentation in Continental Rifts 73, 221-232.

Yuretich, R., Melles, M., Sarata, B., Grobe, H., 1999. Clay minerals in the sediments of Lake Baikal, a useful climate proxy. Journal of Sedimentary Research 69, 588-596.

Zahn, R., Schönfeld, J., Kudrass, H.-R., Pflaumann, U., Sinha, D.K., Park, M.-H., Erlenkeuser, H., 1997. Thermohaline instability in the North Atlantic during Heinrich Events: stable isotope and faunal records from core SO75-26KL, Portuguese margin. Paleoceanography 12, 696-710. 